\title{
Perpustakaan Maya sebagai Sumber Belajar dan Penunjang Pembelajaran IPS secara Daring di Era Pandemi COVID-19
}

\author{
Mochamad Doni Akviansah, S.Pd \\ Fakultas Keguruan dan Ilmu Penddikan, Universitas Sebelas Maret \\ Surakarta, Indonesia \\ akviansah@gmail.com \\ Prof. Dr. Sariyatun., M.Pd. \\ Fakultas Keguruan dan Ilmu Penddikan, Universitas Sebelas Maret \\ Surakarta, Indonesia \\ sariyatun@staff.uns.ac.id
}

\begin{abstract}
This article aimed to describe how important the existence of virtual libraries is as a learning resource in online social studies learning, because virtual libraries provide the widest possible access by anyone, anywhere, anytime to dig up various information that can later be used by students, educators, and even. The principal of this study utilized descriptive qualitative research methods. This research was motivated by the emergence of the Covid-19 outbreak which resulted in many changes and technological developments that drove the comprehensive digitization process. The conditions during a pandemic by requiring online learning are the route chosen to keep the education system running. The role of technology is very visible and very impactful in times like this. In addition to the human resources and supporting technology that are prepared, the components in learning must also be prepared to support learning online. One of these components is a virtual library that is easy to use and useful as a learning resource and learning support. In addition, virtual libraries can improve students' abilities in terms of reading so that they can increase knowledge which has an impact on increasing student achievement.
\end{abstract}

Keywords: online social studies learning, virtual library

\begin{abstract}
Abstrak
Artikel ini bertujuan untuk mendeskripsikan betapa pentingnya keberadaan perpustakaan maya sebagai sumber belajar dalam pembelajaran IPS secara daring, karena di perpustakaan maya menyediakan akses seluas-luasnya oleh siapapun, dimanapun, dan kapanpun untuk menggali berbagai informasi yang nantinya dapat dimanfaatkan oleh peserta didik, pendidik, bahkan kepala sekolah Penelitian ini memanfaatkan metode penelitian kualitatif deskriptif. Penelitian ini dilatarbelakangi oleh kemunculan wabah Covid-19 yang mengakibatkan banyak perubahan dan perkembangan teknologi yang mendorong proses digitalisasi menyeluruh. Kondisi saat pandemi dengan mengharuskan pembelajaran dalam jaringan merupakan jalan yang dipilih agar sistem pendidikan tetap berjalan. Peran teknologi sangat terlihat dan sangat
\end{abstract}




\section{Perpustakaan Maya Sebagai Sumber Belajar dan Penunjang Pembelajaran IPS Secara Daring di Era Pandemi COVID-19}

berdampak disaat kondisi seperti ini. Selain sumber daya manusia dan teknologi penunjang yang disiapkan, komponen-komponen dalam pembelajaran juga harus disiapkan sebagai penunjang pembelajaran dalam jaringan. Salah satu komponen tersebut adalah perpustakaan maya yang mudah dimanfaatkan dan bermanfaat sebagai sumber belajar dan penunjang belajar. Selain itu, perpustakaan maya dapat meningkatkan kemampuan peserta didik dalam hal membaca sehingga dapat meningkatkan pengetahuan yang berdampak pada meningkatnya prestasi peserta didik.

Kata Kunci: pembelajaran IPS daring, perpustakaan maya

\section{PENDAHULUAN}

Kondisi pandemic COVID-19 di jaman serba digital ini mengharuskan semua kegiatan sebisa mungkin dilakukan dari rumah dengan memanfaatkan kecanggihan teknologi. Bidang pendidikan juga salah satu aspek yang merasakan imbas dari pandemic COVID-19. Himbauan pemerintah meniadakan kegiatan yang menimbulkan keramaian akhirnya membuat sekolah tetap berjalan dari rumah atau sekolah dalam jaringan. Terkait kondisi seperti ini, pemerintah mengambil langkah untuk menyusun kurikulum merdeka belajar dimana mendorong semua elemen pendidikan untuk mengaktifkan kelas meskipun sekolah tutup. Proses pembelajaran daring atau dalam jaringan ini pada prakteknya dirasa kurang efektif karena beberapa alasan, salah satunya adalah kurang adanya referensi sebagai sumber penunjang pembelajaran. Selain itu, untuk mengakses sumber belajar harus membeli kuota internet yang mahal. Terlebih lagi, beberapa website yang menyediakan referensi sebagai penunjang pembelajaran terkadang sudah banyak tercemar oleh iklan-iklan yang cukup mengganggu. Alhasil, proses mengunduh cukup sulit dan lama.

Tidak semua pelajaran bisa maksimal di lakukan dengan metode pembelajaran dalam jaringan, apalagi pembelajaran IPS yang banyak membahas ilmu-ilmu sosial dengan cakuan luas. Pembelajaran IPS yang disampaikan dengan daring lebih terkesan pembelajaran satu arah. Waktu yang singkat juga terkadang dimanfaatkan oleh beberapa pendidik untuk memberi tugas yang cukup memakan waktu untuk proses pengerjaannya. Kondisi ini mengakibatkan krisis referensi atau literatur oleh peserta didik.

Bantuan kuota dari pemerintah untuk peserta didik bahkan pendidik sebenarnya sangat membantu proses pembelajaran. Dukungan akses internet seharusnya dimanfaatkan dengan sebaik mungkin oleh pendidik dan peserta didik. Banyak laman yang menyediakan referensi digital, namun sepertinya kurang diketahui pendidik ataupun peserta didik. Kecenderungan dengan memasukkan kata kunci dalam mencari jawaban oleh peserta didik tampaknya telah menjadi kebiasaan. Padahal banyak laman yang menyediakan referensi literatur atau bahan bacaan dengan sumber yang jelas dan dapat dipertanggung jawabkan sehingga dapat meningkatkan pengetahuan peserta didik. Oleh karena itu, artikel ini berusaha membahas tentang refleksi pembelajaran IPS daring, konsep dan praktik pemanfaatan perpustakaan maya sebagai sumber belajar dan penunjang pembelajaran daring mata pelajaran IPS di era pandemi COVID-19. 


\section{METODE}

Metode yang digunakan dalam kajian ini yakni metode penelitian kualitatif, dimana data yang dihasilkan adalah data deskriptif berupa ucapan, tulisan, maupun perilaku orang yang diamati (Bogdan dan Biglen dalam Rahmat, P.S. 2009: 2-3). Data deskriptif pada penelitian ini didapat dengan melakukan analisis isi dari suatu informasi atau teks tertentu yang biasa disebut metode descriptive content analysis study oleh Munirah (2015: 190). Analisis dilakukan pada berbagai artikel ilmiah terkait pembelajaran dalam jaringan (daring) selama masa pandemi COVID-19. Selain analisis isi, peneliti juga melakukan perumusan masalah, penelusuran dan pengumpulan pustaka, pembandingan data yang diperoleh serta penyajian dan setelah itu dilakukan pembahasan hasil kajian. Perumusan masalah dalam artikel ini dilakukan berdasarkan pada bukti-bukti yang teramati oleh indera peneliti terkait pembelajaran IPS secara daring ini. Data yang diperoleh akan dianalisis untuk mencari solusi yang dapat digunakan dalam pembelajaran IPS daring yang minim literatur dan referensi.

Setelah tahap penelusuran data sehingga data-data dan sumber-sumber terkait terkumpul, kemudian dilakukan penyandingan dan pembandingan secara kritis. Pada tahap pembandingan ini, hasil analisis data yang diperoleh akan dibandingkan dengan beberapa sumber dari buku dan artikel terkait bahasan kajian ini. Tahap pembandingan ini sebenarnya tidak sepenuhnya jadi pembanding, tetapi dapat juga dirujuk sebagai pendukung kajian ini. Tahap selanjutnya yakni penyajian data yang bisa dibilang cukup matang dan dilakukan pembahasan yang difokuskan pada refleksi pembelajaran IPS daring, konsep dan praktik pemanfaatan perpustakaan maya sebagai sumber belajar dan penunjang pembelajaran daring mata pelajaran IPS di era pandemi COVID-19.

\section{HASIL DAN PEMBAHASAN}

\section{Refleksi Pembelajaran IPS dalam Jaringan (Daring)}

Virus Corona atau yang disebut juga COVID-19 pertama kali terdeteksi di kota Wuhan, Tiongkok sekitar akhir tahun 2019. Penyebaran yang begitu cepat mendorong pemerintah Indonesia membuat beberapa kebijakan yang bertujuan untuk memutus rantai penyebaran virus ini. Beberapa kebijakan yang dilakukan mulai dari anjuran untuk melaksanakan social distancing hingga PSBB (Pembatasan Sosial Skala Besar). Pandemi seperti ini merupakan pandemi global pertama di era serba digital. Tak tanggung-tanggung, imbas adanya pandemic ini sudah dirasakan seluruh aspek, tak terkecuali bidang pendidikan. Alhasil, bidang pendidikan memilih jalan untuk melakukan pembelajaran secara daring (dalam jaringan) atau online. Pembelajaran secara daring atau online dapat diartikan sebagai proses pengalaman transfer pengetahuan menggunakan video, audio, gambar, komunikasi teks, dan perangkat lunak (Basilaia \& Kvavadze, 2020). Lebih lanjut, Basilia dan Kvavadze (2020) juga mengungkapkan bahwa pembelajaran online ini merupakan modifikasi transfer pengetahuan melalui forum website. Dalam proses transfer tersebut harus didukung oleh jaringan internet. 


\section{Perpustakaan Maya Sebagai Sumber Belajar dan Penunjang Pembelajaran IPS Secara Daring di Era Pandemi COVID-19}

Tentu saja hal ini menjadi tantangan tersendiri bagi kita semua, terutama pendidik dan peserta didik dikarenakan memerlukan persiapan dari segi infrastruktur hingga proses adaptasi yang berbeda dibanding pembelajaran tatap muka. Inilah ciri khas revolusi industri 4.0 dengan tren serba digital yang harus dimanfaatkan sebagai pembelajaran selama pandemi ini.

Proses pembelajaran secara daring pada praktiknya memang belum bisa dibilang maksimal. Banyak kendala-kendala yang ditemui saat proses pembelajaran secara daring ini. Kendala tersebut meliputi pemotongan waktu pembelajaran yang singkat dikarenakan pertimbangan biaya yang diperlukan untuk membeli kuota internet yang mahal. Selain itu, kurangnya pendidik yang menguasai IPTEK tampaknya juga menjadi masalah serius. Alhasil, pendidik yang kurang menguasai IPTEK hanya memberikan tugas-tugas tanpa ada refleksi dalam pembelajaran. Kondisi ini mengakibatkan kurangnya pengetahuan oleh peserta didik dikarenakan minimnya pengetahuan peserta didik tentang bagaimana cara mendapatkan literatur saat pembelajaran dalam jaringan ini.

Menyadari hal tersebut, Kemdikbud telah mengupayakan beberapa bantuan belajar terhadap pendidik maupun peserta didik. Bantuan tersebut dalam bentuk kuota internet yang rencananya akan diberikan tiap bulan selama proses pembelajaran berlangsung. Selain itu, Kemdikbud juga telah bekerja sama dengan stasiun televisi Nasional, yakni TVRI dalam rangka penyediaan konten pembelajaran jarak jauh. Hal ini merupakan bagian dari pemanfaatan segala sumber daya lokal secara nasional seperti saluran televisi untuk edukasi (Zhou et al., 2020). Kini, Kemdikbud juga telah menyiapkan perubahan kurikulum yang akrab dikenal dengan kurikulum merdeka belajar dimana memang disiapkan menghadapi model pembelajaran secara daring ini.

Lebih lanjut mengenai pembelajaran daring, di situasi seperti ini sangatlah dibutuhkan pendidik yang inovatif dalam pembelajaran daring, salah satunya pembelajaran IPS daring. IPS atau Ilmu Pengetahuan Sosial merupakan mata pelajaran yang diberikan pada tingkatan Sekolah Dasar (SD) hingga Sekolah Menengah Pertama (SMP) yang mencakup disiplin ilmuilmu sosial mulai dari sosiologi, ekonomi, geografi, sejarah, tata Negara, hingga antropologi. Sifatnya yang terpadu atau integrated dari sejumlah mata pelajaran menjadikan mata pelajaran IPS memiliki ciri khas tersendiri. Menurut Sapriya, (2015: 7) tujuan dari sifat integrated mata pelajaran IPS sendiri yakni agar mata pelajaran IPS lebih bermakna bagi peserta didik sehingga pengorganisasian materinya disesuaikan dengan lingkungan, karakteristik, dan kebutuhan peserta didik. IPS sendiri merupakan disiplin ilmu sosial yang erat sekali kaitannya dengan sistem lingkungan (alam dan manusia). Sehingga output yang diharapkan dari mata pelajaran IPS yakni agar peserta didik berkembang dalam segi pengetahuan, keterampilan, dan nilai, serta dapat menjadi warganegara yang berpartisipasi aktif dalam masyarakat yang demokratis.

Soemantri (dalam Sapriya, 2015: 11) berpendapat bahwa pendidikan IPS merupakan penyederhanaan atau adaptasi dari disiplin ilmu-ilmu sosial dan humaniora serta kegiatan dasar manusia yang diorganisasikan dan disajikan secara ilmiah dan pedagogis/psikologis untuk tujuan pendidikan. Maka tak heran jika pembelajaran IPS ditingkat sekolah memiliki tujuan 
menyiapkan peserta didik sebagai warga Negara yang menguasai pengetahuan, keterampilan, sikap, dan nilai sehingga memiliki kemampuan untuk memecahkan masalah pribadi atau masalah sosial atau juga kemampuan dalam mengambil keputusan. Selain itu, peserta didik juga diharapkan menjadi aktif berpartisipasi dalam kegiatan kemasyarakatan di lingkungannya. Oleh karena itu, dalam pembelajaran IPS sangatlah dibutuhkan sumber-sumber informasi yang ada disekitar kehidupan masyarakat, agar pembelajaran dalam IPS terus berkembang seiring dengan perkembangan zaman (Sapriya, 2015: 12)

Pembelajaran IPS secara daring dapat dimanfaatkan dengan penggunaan Platform online seperti Zoom, Google meet, Google Classroom, Edmodo dll. Namun, pada prakteknya, pendidik lebih banyak memberikan tugas tanpa adanya penguatan atau refleksi. Disamping itu, selama pembelajaran daring ini peserta didik akan miskin literatur jika tidak di arahkan untuk memanfaatkan literatur online dengan baik oleh para pendidik.

Sebenarnya, pembelajaran IPS secara daring ini merupakan kesempatan pendidik dan peserta didik untuk berkembang. Hal ini dikarenakan pembelajaran sejarah secara daring merupakan pembelajaran yang fleksibel. Artinya, pembelajaran sejarah dapat dilakukan dimana saja dan kapan saja. Kunci dari pembelajaran secara daring atau online ini adalah untuk melakukan pembelajaran online sesuai dengan kondisi setempat (Zhang et al., 2020). Selain itu, diperlukan juga pemanfaatan literatur online yang telah tersedia di beberapa laman dan platform online. Pemanfaatan literatur online diperlukan peserta didik agar mempunyai sesuatu yang dapat menunjang pembelajaran IPS secara daring maupun secara mandiri dimanapun dan kapanpun sehingga lebih menguasai materi yang diberikan oleh pendidik dengan sumber yang kredibel.

\section{Perpustakaan Maya}

Sudah tidak asing jika kita mendengar kata perpustakaan. Selama ini kita telah mengetahui perpustakaan di sekolah yang berperan sebagai penunjang pembelajaran. Selain sebagi penunjang, perpustakaan juga berperan sebagai sumber belajar. Sumber belajar disini maksudnya yakni semua bahan atau sumber informasi, sumber alat, sumber peraga yang dapat digunakan dalam proses pembelajaran. Perpustakaan tergolong sebagai sumber belajar karena dalam perpustakaan terdapat bahan dan sumber informasi yang memiliki peranan penting dalam membantu proses belajar mengajar. Secara teori, perpustakaan memiliki pengertian sarana akademis yang menyediakan bahan-bahan pustaka berupa barang cetakan seperti buku, majalah/jurnal ilmiah, peta, surat kabar, karya-karya tulis berupa monogarf yang belum diterbitka, serta bahan-bahan non cetak seperti microfish, micro film, foto-foto, film, kaset audio/video, lagu-lagu dalam piringan hita, rekaman pidato (dokumenter) dan lain lain (Sianipar, 2012).

Pengertian perpustakaan tersebut menunjukkan pentingnya peran perpustakaan jika dimanfaatkan secara maksimal dan efektif, maka peran perpustakaan ini dapat membantu 


\section{Perpustakaan Maya Sebagai Sumber Belajar dan Penunjang Pembelajaran IPS Secara Daring di Era Pandemi COVID-19}

peserta didik dalam membangun motivasi belajar yang tinggi sehingga peserta didik akan lebih mudah dalam meraih prestasi belajar. Berdasarkan teori yang dikemukakan oleh Bafadal (2012: 5) bahwa salah satu manfaat perpustakaan adalah peserta didik dapat menimbulkan kecintaan terhadap membaca dan dapat mempercepat proses penguasaan teknik membaca. Penelitian yang disampaikan Ohiowutun semakin memperkuat pernyataan, Ohiowutun, Worouw dan Turang (2014) yang menyatakan bahwa dengan memanfaatkan koleksi yang ada di perpustakaan dapat mempengaruhi minat membaca mahasiswa atau siswa. Meningkatnya minat baca oleh peserta didik secara tidak langsung akan membentuk pola pikir peserta didik. Pola pikir tersebut akan berdampak pada peningkatan cara berkomunikasi secara interpersonal dalam kegiatan belajar-mengajar. Sehingga peserta didik tidak akan malu lagi untuk aktif dalam kelas, seperti bertanya, menjawab, bahkan menghargai pendapat dalam kelas. Alhasil pembelajaran dalam kelas akan berjalan dengan baik.

Dewasa ini, perkembangan teknologi yang begitu pesat membawa kita pada jaman dimana semuanya serba digital. Proses digitalisasi pun terjadi dalam semua aspek kehidupan, salah satunya dibidang pendidikan yakni proses digitalisasi liteatur. Proses digitalisasi literatur ini yang banyak disebut dengan Revolusi Digital yang membawa kita ke Perputakaan Era Baru yang sering disebut sebagai Perpustakaan maya atau perpustakaan digital ataupun e-library. Kini kita telah banyak menemui perpustakaan maya saat menjelajahi internet. Hal ini salah satu bukti bahwa perpustakaan telah berlomba-lomba memanfaatkan website untuk meningkatkan sumberdaya informasi yang dimiliki melalui media elektronik menuju e-library ataupun perpustakaan maya. Namun demikian, sebagian situs perpustakaan maya belum bisa berhasil sepenuhnya diminati oleh para penggunanya dikarenakan kurangnya panduan penggunaannya.

Berbicara mengenai perpustakaan maya atau perpustakaan digital, secara konseptual perpustakaan maya dapat dimaknai sebagai cerminan koleksi dan layanan perpustakaan dalam dunia fisik atau analog dari perpustakaan tradisional dalam hal keragaman dan kompleksitas koleksinya, dan isinya berupa media elektronik. Hal ini sesuai dengan apa yang dikatakan oleh Subrata (2009: 1) yang berpendapat bahwa perpustakaan maya atau digital adalah penerapan teknologi informasi sebagai sarana untuk menyimpan, mendapatkan dan menyebarluaskan informasi ilmu pengetahuan dalam format digital. Atau secara sederhana dapat dianalogikan sebagai tempat menyimpan koleksi perpustakaan yang sudah dalam bentuk digital. Perpustakaan maya juga dapat dibilang sebagai suatu jaringan dari beberapa perpustakaan yang telah terhubung dengan berbagai sumber informasi dan layanan serta dibukanya akses publik dimanapun dan kapanpun serta oleh siapapun. Jadi secara istilah dapat dipahami bahwa karakteristik dari perpustakaan non tradisional ini cenderung pada penggunaan teknologi, dalam hal ini komputer dan internet dalam mengelola koleksi dan layanannya.

Lebih lanjut mengenai karakteristik, perpustakaan maya memiliki koleksi berbentuk digital, seperti e-book, gambar, suara atau video yang dapat diakses secara online dimana dan kapanpun. Lain halnya dengan sistem otomasi perpustakaan yang sering kita jumpai dengan ciri hanya terdapat sajian metadata berupa deskripsi bibliografi. Pengguna perpustakaan maya 
dapat mengakses teks secara full. Selain itu, disebut perpustakaan maya, jika memenuhi beberapa karakteristik berikut ini (Ted \& Large, 2005: 16):

1. Memuat informasi dalam bentuk digital;

2. Memiliki jaringan;

3. Terdiri dari data lengkap dan juga meta data yang menggambrakan data tersebut;

4. Memiliki koleksi yang terorganisasi dan telah diseleksi sesuai dengan kebutuhan masyarakat penggunanya;

5. Merupakan perluasan, pengembangan dari perpustakaan tradisional;

6. Menekankan pentingnya stabilitas ketersediaan koleksi.

Melihat beberapa karakteristik diatas, manfaat dari adanya perpustakaan maya ini sudah dapat di prediksi seperti pengguna bisa mengakses perpustakaan maya dimanapun dan kapanpun, memungkinkan untuk mengakses teks secara full. Selain itu, ada beberapa kelebihan perpustakaan maa dibanding perpustakaan tradisional, yakni:

1. Tidak terbatas oleh ruang dan waktu;

2. Lebih efisien karena tidak harus ke perpustakaan langsung;

3. Jaringan perpustakaan lebih luas;

4. Lebih murah biaya pemeliharaan koleksi dan biaya pengadaannya;

5. Keaslian dokumen tetap terjamin;

6. Akses informasi akan semakin mudah;

7. Sistem penyimpanan dan pelestarian dokumen yang baik.

Kondisi serba digital saat ini dengan adanya pandemic, membuat semua dilakukan dengan jarak jauh dengan memanfaatkan jaringan, salah satunya sekolah. Adanya perpustakaan maya ini merupakan solusi berdasarkan kondisi terkini karena masyarakat membutuhkan kemudahan akses informasi dengan cepat dan praktis tanpa harus datang ke perpustakaan terlebih dahulu untuk mencari literatur. Namun, perlu diingat juga bahwasanya diperlukan kewaspadaan mengenai persoalan hak cipta dan kendala teknis lainnya dalam mengakses literatur.

\section{Pemanfaatan Perpustakaan Maya Sebagai Sumber Belajar dan Penunjang Pembelajaran IPS Secara Daring}

Selama ini, di setiap sekolah telah terdapat perpustakaan dengan kondisi, koleksi, dan pelayanan yang berbeda-beda. Perpustakaan telah menjadi bagian integral dari lembaga sekolah karena dalam perpustakaan telah tersedia bahan atau sumber belajar yang dapat membantu semua penghuni sekolah, mulai dari kepala sekolah, pendidik, hingga peserta didik. Perpustakaan berperan penting dalam membantu kepala sekolah dan pendidik dalam mengembangkan kurikulum dan bahan ajar untuk memaksimalkan proses belajar peserta didik. Peserta didik juga dapat mengembangkan potensinya dengan membaca sumber belajar di perpustakaan. Oleh karena itu, tak heran jika sekolah-sekolah memanfaatkan perpustakaan sebagai bagian integral sekolah. Jadi, perpustakaan disini juga merupakan penunjang dalam meningkatkan sumber belajar yang sekaligus sebagai wadah dari berbagai disipilin ilmu 


\section{Perpustakaan Maya Sebagai Sumber Belajar dan Penunjang Pembelajaran IPS Secara Daring di Era Pandemi COVID-19}

pengetahuan yang juga menunjang atau sebagai sarana dalam mencerdaskan kehidupan bangsa khususnya dibidang pendidikan N. Sari, \& A. Setyadi (2017).

Namun, terkadang pemanfaatan perpustakaan di sekolah tidaklah berjalan semestinya dikarenakan pengelolahan yang kurang professional menjadikan perpustakaan kurang bermanfaat dan dianggap tidak lebih dari gudang buku. Padahal pelajaran-pelajaran di sekolah sangat membutuhkan sumber belajar atau sumber referensi lain dan sumber belajar itu dapat ditemukan dalam perpustakaan. Seperti mata pelajaran IPS yang memerlukan sumber belajar segala peristiwa atau kejadian, orang, buku, dan terutama lingkungan. Dalam hal ini, perpustakaan menempati posisi sebagai sumber belajar yang menyediakan kumpulan pustaka dan lingkungan belajar peserta didik.

Apalagi dalam kondisi serba digital dan diperparah adanya pandemic COVID-19, peran perpustakaan semakin dibutuhkan selama sekolah dalam jaringan. Alhasil, pemanfaatan perpustakaan maya seakan menjadi kebutuhan dalam pembelajaran, tak terkecuali pembelajaran IPS. Kondisi pembelajaran IPS daring dan anjuran diam dirumah demi memutus rantai penyebaran virus Corona akan menyempitkan sumber belajar peserta didik. Alhasil, pembelajaran kurang efektif. Adanya perpustakaan maya dengan digitalisasi literatur yang telah tersedia akan sangat membantu peserta didik, pendidik, bahkan semua orang.

Pada prakteknya, pembelajaran IPS secara daring dirasa masih kurang efektif dikarenakan pendidik cenderung memberi tugas tanpa memberikan refleksi. Pertemuan yang singkat di dunia maya dan dilanjut dengan tugas yang diberikan akan membuat peserta didik hanya terpaku pada pengerjaan tugas saja. Hal ini tidak akan efektif karena peserta didik kurang terlatih kemampuannya dalam menemukan literasi dan informasi untuk menyelesaikan tugas yang diberikan oleh pendidik. Padahal, peningkatan kemampuan literasi dan informasi akan berdampak langsung pada peningkatan prestasi belajar siswa. Hal ini sesuai dengan hasil penelitian Hasil penelitian ini juga diperkuat oleh hasil penelitian Lenawati\& Siswanto (2012) yang menyatakan bahwa semakin memanfaatkan perpustakaan, maka semakin meningkat prestasi peserta didik.

Secara keuntungan, sebenarnya saat ini kita telah diuntungkan dengan fasilitas di masa pandemic yang sudah disiapkan sedemikian rupa dan didukung oleh perkembangan teknologi. Fasilitas-fasilitas seperti bantuan kuota internet oleh pemerintah, digitalisasi sumber-sumber dan adanya perpustakaan maya sangat mendukung pembelajaran IPS secara daring. Beberapa perpustakaan maya seharusnya sudah diketahui bahkan dimanfaatkan pendidik untuk di aplikasikan dalam pembelajaran, seperti Edmodo, Perpusnas, Internet Archive, dan menurut (Yuadi, 2007) website perpustakaan universitas yang tergabung dalam Indonesia Digital Library Network (IndonesiaDLN). Pemanfaatan perpustakaan maya akan menguntungkan jika dimanfaatkan dengan baik. Seperti di platform online Edmodo yang menyediakan fitur backpack yang didalamnya kita bisa menyimpan file atau arsip penting dalam berbagai bentuk dan format seperti link, dokumen, video, audio dalam jumlah tak terbatas. Terlebih lagi jika pendidik sudah bisa memanfaatkan aplikasi Perpusnas, dimana aplikasi tersebut mempunyai 
fitur yang sama seperti perpustakaan tradisional namun kita bisa melakukannya melalui smartphone kita. Jadi kita bisa leluasa memilih buku dan meminjamnya. Lain halnya dengan perpustakaan maya yang dimiliki universitas dimana kita data mengakses secara full teks skripsi, jurnal, artikel, bahkan thesis.

Melihat perkembangan teknologi yang pesat dan sudah cukup banyak efek yang ditimbulkan, adanya perpustkaan maya di masa pandemic ini akan merubah paradigma masyarakat terhadap perpustkaan tradisional. Hal ini dikarenakan perpustakaan maya lebih efisien karena tidak memerlukan bangunan fisik sehingga secara ekonomis lebih hemat dimana penyimpanan hanya pada memori penyimpanan pada komputer. Alhasil, semua orang dapat membuka akses terhadap informasi yang telah dipublikasikan karena kemudahan sistem yang dimiliki perpustakaan maya.

Selain itu, adanya pemanfaatan perpustakaan maya akan membuat akses informasi semakin mudah dan proses belajar mengajar, penelitian dan pengembangan ilmu pengetahuan akan mudah dilakukan. Pemanfaatan perpustakaan maya di masa pandemic seperti ini merupakan solusi bagi pembelajaran karena informasi bisa diakses secara mudah, cepat dan praktis. Namun tantangan yang sesungguhnya adalah paradigma peserta didik sendiri yang telah terbiasa bergantung kepada pendidik saat pembelajaran, bergantung pada layanan tatap muka secara langsung, dan terbatas pada buku pelajaran yang mereka punya sendiri akan sangat menghambat pemanfaatan perpustakaan maya sebagai sumber belajar dan penunjang pembelajaran IPS secara daring. Maka diperlukan peran pendidik untuk mengubah paradigma tersebut. Hal ini sesuai pendapat N. Sari, \& A. Setyadi (2017) bahwa kemampuan dalam memanfaatkan perpustakaan untuk mengembangkan setiap mata pelajaran di sekolah sangat tergantung pada kemampuan pendidik IPS itu sendiri dalam mengkreasikan serta menerapkan semua yang ada disekitarnya.

\section{SIMPULAN}

Pandemi COVID-19 merupakan pandemic global pertama di era serba digital yang berdampak pada semua aspek tak terkceuali di bidang pendidikan. Himbauan sekolah tetap berjalan tanpa tatap muka menjadikan pembelajaran dilakukan secara daring atau dalam jaringan. Efektivitas pembelajaran daring ini kurang baik pada pelaksanaanya dikarenakan banyak pendidik cenderung memberi tugas. Pembelajaran yang seperti ini tidak bisa efektif pada mata pelajaran seperti IPS dimana disiplin ilmu sosial ini erat sekali kaitannya dengan sistem lingkungan (alam dan manusia). Disiplin ilmu ini memerlukan sumber belajar yang luas mengingat sifatnya yang mencakup sistem lingkungan alam dan manusia. Sedangkan pembelajaran IPS secara daring sangat minim sumber belajar dan penunjangnya karena pendidik banyak memanfaatkan untuk memberi tugas.

Adanya perpustakaan maya merupakan solusi pembelajaran IPS secara daring. Hal ini dikarenakan perpustakaan maya memuat literatur yang telah di digitalisasi dan aksesnya sendiri dibuka seluas-luasnya sehingga dapat diakses oleh siapapun, kapanpun, dan dimanapun. Perpustakaan maya sendiri perlu dimanfaatkan mengingat kemudahan sistem yang ditawarkan, efisiensi, dan secara ekonomis lebih murah karena tidak memerlukan pembangunan gedung 


\section{Perpustakaan Maya Sebagai Sumber Belajar dan Penunjang Pembelajaran IPS Secara Daring di Era Pandemi COVID-19}

penyimpanan. Apalagi pengguna perpustakaan maya dapat mengakses teks secara full sehingga jika di aplikasikan kepada peserta didik akan meningkatkan kemampuan literasi dan komunikasi peserta didik. Meningkatnya kemampuan literasi akan berdampak pada peningkatan prestasi peserta didik. Dewasa ini, telah banyak platform digital yang menyediakan fasilitas perpustakaan maya, seperti Internet Archive, Edmodo, Perpusnas, hingga website-website universitas yang tergabung dalam IndonesiaDLN (Indonesia Digital Library Network). Adanya fasilitas penunjang pembelajaran IPS secara daring seperti perpustakaan maya dan ditambah dengan adanya bantuan kuota dari pemerintah merupakan titik terang permasalahan pembelajaran daring ini sehingga kemampuan literasi dan komunikasi peserta didik akan terus berkembang serta prestasi peserta didik akan meningkat.

\section{DAFTAR PUSTAKA}

Bafadal, Ibrahim. 2015. Pengelolaan Perpustakaan Sekolah. Jakarta: Bumi Aksara.

Basilaia, G., \& Kvavadze, D. (2020). Transition to Online Education in Schools during a SARS-CoV-2 Coronavirus (COVID-19) Pandemic in Georgia. Pedagogical Research, 5(4). https://doi.org/10.29333/pr/7937.

Lenawati, Ade \& Siswanto. 2013. Pengaruh Motivasi Belajar dan Pemanfaatan Perpustakaan

Sekolah Terhadap Prestasi Belajar Akuntansi Siswa Kelas X Program Keahlian Akuntansi SMK YPKK 1 Sleman Tahun Ajaran 2011/2012. JKPAI, 2(1), pp. 31-71.

Munirah, F. 2015. Analisis Isi Deskriptif Rubrik "Xp Re Si" Harian Kaltim Post Periode Maret-April 2013. EJurnal Ilmu Komunikasi. 3(1), pp. 186-197.

N. Sari \& A. Setyadi. 2017. Pemanfaatan Perpustakaan Oleh Guru Ips Dalam Menunjang Kegiatan Belajar-Mengajar Di Sma Negeri 2 Purbalingga. Jurnal Ilmu Perpustakaan. 6(1), pp. 311-320.

Ohoiwutun. V, Warouw. D, Turang.M. 2014. Pengaruh Manajemen Koleksi Perpustakaan Terhadap Minat Baca Mahasiswa Jurusan Ilmu Keperawatan Universitas Katolik De La Salle Manado. Acta Diurna. 3(2), pp. 1-13.

Rahmat, P, S, 2009. Penelitian Kualitatif. Equilibrium, 5(9), pp. 1-8.

Sapriya. 2015. Pendidikan IPS. Bandung: PT Remaja Rosdakarya.

Saleman, Sianipar. 2011. Hubungan Antara Pemanfaatan Sumber Belajar Perpustakaan Dan

Komunikasi Interpersonal Dengan Hasil Belajar Sosiologi Siswa Kelas X SMA Swasta Se-Kecamatan Sunggal. TABULARASA (JURNAL PENDIDIKAN PPS UNIMED). 8(2), pp. 135-148.

Subrata, Gatot. 2009. Perpustakaan Digital. Pustakawan Perpustakaan UM: Malang.

Lucy A. Tedd and Andrew Large. 2005. Digital Libraries: Principles and Practices in a Global Environment. Munich: K. G. Saur.

Yuadi, Imam. 2007. Perpustakaan Digital: Paradigma, Konsep dan Teknologi Informasi yang Digunakan. Masyarakat Kebudayaan dan Politik. 19(4), pp. 29-47.

Zhang, W., Wang, Y., Yang, L., \& Wang, C. (2020). Suspending Classes Without Stopping Learning: China's Education Emergency Management Policy in the COVID-19 Outbreak. Risk and Financial Management, 13(55), 1-6. https://doi.org/doi:10.3390/jrfm13030055. 
Zhou, L., Li, F., Wu, S., \& Zhou, M. (2020). "School's Out, But Class's On”, The Largest Online Education in the World. Today: Taking China's Practical Exploration During The COVID-19 Epidemic Prevention and Control as An Example. The Largest Online Education in the World Today, 4(2), 501-519. https://doi.org/10.15354/bece.20.ar023. 